\title{
Counseling of Self Management Assessment to Negative Mentality of College students
}

\author{
Liu Jing ${ }^{1, \text { a }}$ \\ ${ }^{1}$ QingdaoUniversity of Scienc\&Technology qingdao shandong 266061 \\ aanglej@126.com
}

Keywords: self management assessment; college students; negative mentality

\begin{abstract}
Negative mentality is a non-rational psychological, which is widespread in learning process of college students, and the students' learning and healthy growth is seriously affected by it. College students are taught to evaluate self management, by the teacher's analysis of the representations and causes of negative mentality. Self management assessment can do the negative mentality counseling, have the students take the initiative in learning, and improve the learning achievement. Statistics of many college students show that self management assessment can relieve students' negative mentality reasonably, and improve their learning enthusiasm widely and effectively.
\end{abstract}

\section{Introduction}

Negative mentality is a special kind of opposition, and is counter intuitive psychology when the individual in the acceptance of foreign education, standards, restrictions. Higher college students will have Negative and radical emotions if they have negative mentality ${ }^{[1]}$. And also they cannot accept the right education, which will not only reduce the learning achievement, and affect the world outlook, outlook on life and values.

Self management is the drive of responsibility, which can give play to the subjective initiative of individual, self regulation and self motivation, and realize the maximization of benefits to reach the target ${ }^{[2]}$. Self education is the foundation for the realization of self management, self management of students, is a student to manage their own, from a management to management, from unconscious to conscious process. Self management assessment can promote students to a correct understanding of their own, to actively explore new ways of students' self promotion, encourage students to constantly adjust their own state of mind ${ }^{[3]}$, to correct the mistakes of the past, and improve student achievement.

\section{Several main performance of College students' negative mentality}

1. Students do not agree and trust the teachers' lectures, and ignore the teachers' persuasion. Facing of the teachers' task, they act in a diametrically opposite way. They not only hate to join the learning activities group, but also disturb other students’ learning environment and collective honor.

2. Students have no example of consciousness for the excellent students, even contain contempt, indi fference and bad mood, whose are lack of positive enterprising and correct learning attitude.

3. Students have negative attitude on their own learning, and have no effective learning goals and pl anning $^{[4-6]}$, whose cannot treat correctly the teacher's teaching and criticism, take back, show no respect to elders and superiors.

4. Students think their own bad behavior as a manifestation of personality, and think they are out of $t$ he ordinary learning attitude as a so-called "cool", think that they can get appreciate of other classmates. 
They ignore intellectual importance for the fate of themselves, influenced by hedonism, extreme indivi dualism, tired and reverse psychology of learning.

\section{Reasons of College students' negative mentality}

The cause of negative mentality of college students includes their own quality reasons, family reasons, education reasons and social reasons.

\section{A.The own reasons of college students' negative mentality.}

Students being at the stage of development psychology, have a strong independent consciousness and self consciousness, and are lack of experience of society's awareness and understanding. When they are stimulated by the teachers or parents, they will do stupid things. The students' thinking are radical and innovative, are unwilling to use the analysis of the traditional methods of knowledge. They have the contradiction psychology for parents and teachers' taught, and question all of the knowledge. Some students have serious inferiority, and lack of self-confidence when facing the complicated knowledge. At all long-term development they will cause severe psychological pressure, and eventually give up learning and have a reverse psychology of learning.

\section{B. The family reasons of college students' negative mentality.}

Parents expect their children to learn the value very well, and hope that through their own life experience and value of children, parents and children are lack of effective communication. The students who are thought to have mature thought have a negative psychological learning enthusiasm. Some students ignore the importance of knowledge, just consider for the sake of hedonism, expect home help or other conditions to attain the highest level in one step, think learning useless, have neither learning nor skill, and reverse psychology of learning.

\section{The teacher reasons of college students' negative mentality.}

Teachers who pay too much attention to improve student achievement neglect the students' study psychological situation, learning ability and learning enthusiasm. Some teacher who lack of occupation accomplishment or have a lower level of education, take the spoon feeding education, attempt to force plug knowledge to the students. In this way, the students cannot understand the knowledge well, and have strong negative emotions. Some teacher who are lack of occupation moral, do not care about the poor performance in school learning. The adverse emotional development eventually causes the student to have a reverse psychology of learning.

\section{The school reasons of college students' negative mentality.}

The school rules and regulations are not perfect. In recent years, the schools which are under the academic pressure, take emphasis on students' learning achievement, and take the results as the standard, are lack of Ideological and political education for students. Particularly in the examination, some irregular ways appeared, such as finding someone to test. But also these students can get better exam results, which will bring negative influence to the good student who will have conflicted emotions in learning.

\section{E. The social factors of college students' negative mentality.}

The present stage of our country is still in the period of social transformation, and the injustice is generally everywhere. The students often feel confused and know the incapable action, and they also think learning useless, cynicism about learning, try to through other means to realize their goals. In 
addition, along with the social economy's rapid development, hedonism, extreme individualism breeds, the students are vulnerable to be influenced by these bad ideas.

\section{Counseling of Self Management Assessment to Negative Mentality of College Students}

Learning is the main task of higher vocational students, and students' reverse psychology will affect students' learning smoothly. Especially in the process of education and teaching, the relationship between teachers and students are not handled properly, which will directly affect the education effect. The self management evaluation by students can effectively ease the students' learning, enhance the enthusiasm of students. Many of our outstanding teachers in the teaching process create a good educational environment by evaluating the ability of self management of students. Zheng Yuxiang who is a teacher of Liaoning University School of business and management puts forward that self management to enhance students' evaluation ability can enhance the students' comprehensive ability, logic analysis decision ability and energy to solve problems themselves. Modern management guru Peter Drucker early took "management method" for evaluating and improving their learning ability until success.

For the reasons of college students' reverse learning psychology of above analysis, teachers teach students to take the self management evaluation method to complete counseling reverse learning psychology of students, promote the development of teaching and learning. Specific methods are as follows:

\section{A. Teachers should improve self quality.}

Educators should constantly improve their quality, including psychological quality, teaching professional ability and the occupation moral level, and pay attention to encourage and praise students' strengths and achievements, and become good teachers and helpful friends. Teachers should improve their teaching level, be careful prepare to ensure that impart knowledge organized, accuracy, interesting, and have the targeted teaching according to different student learning. When teachers who have a noble personality, they can become a learning model. And students will no longer consider teachers as the opposite object, also will listen to the teacher's teaching, actively strive to learn, so as to form a sound learning psychology.

\section{B. Teachers should teach students about their reversal learning psychological abuse.}

The teachers should take the analysis of antagonistic psychological reasons with their students, and help them recognize the dangers of treason bringing to themselves and the people around. Students have a correct understanding of their own advantages and disadvantages, and give full play to their own advantages, enhance the ability to distinguish right from wrong when understanding their psychological defects of reversal learning.

\section{Self psychological adjustment.}

The students should pay attention to the self psychological adjustment, analysis methods of empathy, learn tolerance and calm. With understanding teachers and right teach from parents, they gradually realize the importance of their own shortcomings and the importance of learning, eliminate the reverse psychology of learning, establish healthy psychology of learning.

\section{Self motivation.}

The teachers taught the students to enhance their learning confidence through self motivation methods, which can reduce the psychological pressure on students through the state and psychological 
transfer method and self tolerance method. In order to form a positive learning attitude, the students have to face the complex knowledge or seek help to solve the corresponding problem. Teachers should give full play to the initiative of the students, make them self regulating and self motivation, elimination of reverse psychology of learning.

\section{E. Set up the consciousness of management.}

Strengthen students' self-management consciousness will plan and implement the corresponding learning plan according to the different stages of learning objectives, and eventually form its own unique learning strategies. At last, the students can give full play to their potential, enhance their own collective value, establish a correct sense of collective learning, communicate with other people in learning and experience, eliminate its negative learning psychology, gradually get into a virtuous learning environment.

\section{F. Set a reasonable self management goal.}

Setting up perfect self management goal, is not only considered from the need of individual development of both groups, but also took account of the self management. Self management target groups are mainly took the class (or a group) as a unit. The goal of the group's self management can be a supervisory role for itself, or between the members of a group, which can encourage each other, supervise learning process, and eliminate the antagonistic psychology of learning of all members.

\section{G. Self reinforcing.}

The teacher urges the students to adhere to the self management, eliminate the reverse psychology of learning by positive and negative reinforcement methods. When the students can use the positive and healthy psychology of learning to learn, teachers should give students related reward through positive reinforcement, such as praise, awards, bonus or promotion to enhance the power and the enthusiasm of the students. When the students appear negative learning psychology, teachers should give punishment for students by negative reinforcement method, such as criticism, demotion, urging the students to adhere to the self management, establishing a correct attitude towards learning, eliminating the reverse psychology of learning finally.

\section{H. Self management in the learning and life.}

When the students managing and planning their own learning and life using self management, teachers should not take too much intervention of students, and only give the corresponding instruction to the students. When the students gradually adapt to the self management method with high efficiency and health, their learning and life will be healthy and orderly, which not only can improve student achievement, but also conducive to building the students' the correct outlook on life, values and world outlook.

\section{To verify the effectiveness of the self evaluation management method}

The questionnaire survey method was used to verify the effectiveness of the self management evaluation for psychological counseling to students. On the questionnaire survey of 100 higher college students from a school of one grade, who are between 20-23 years old, and the average age is 21 years old. Letting students fill in reversal learning psychological questionnaire, talking with them, and understanding the details of the antagonistic psychology of learning. There are 45 students in different types of reversal learning psychology, a total of 300 cases. The Statistic of different reversal learning psychological situation was described in table 1. 
Table 1 Statistics of student negative mentality

\begin{tabular}{|c|c|c|c|c|c|c|c|c|c|c|}
\hline $\begin{array}{l}\text { Negative } \\
\text { mentality } \\
\text { type }\end{array}$ & $\begin{array}{l}\text { Aversion } \\
\text { learning }\end{array}$ & $\begin{array}{l}\text { Contradictin } \\
\text { g teachers }\end{array}$ & $\begin{array}{l}\text { Learning } \\
\text { useless }\end{array}$ & $\begin{array}{l}\text { Not agree } \\
\text { with } \\
\text { teaching } \\
\text { content }\end{array}$ & $\begin{array}{l}\text { Hating } \\
\text { collective } \\
\text { learning } \\
\text { activities }\end{array}$ & $\begin{array}{c}\text { Lack of } \\
\text { ambition }\end{array}$ & $\begin{array}{c}\text { Lack of } \\
\text { clear } \\
\text { goals }\end{array}$ & $\begin{array}{l}\text { Lack of } \\
\text { learnin } \\
\text { g plan }\end{array}$ & $\begin{array}{l}\text { Advocating } \\
\text { personal } \\
\text { independence } \\
\text { of conduct } \\
\text { personality }\end{array}$ & $\begin{array}{l}\text { Passive } \\
\text { learning }\end{array}$ \\
\hline times & 75 & 35 & 55 & 60 & 25 & 5 & 20 & 10 & 5 & 10 \\
\hline percent\% & 25 & 12 & 18 & 20 & 8.3 & 1.7 & 6.7 & 3.3 & 1.7 & 3.3 \\
\hline
\end{tabular}

The analysis of Table 1 show that, the main negative learning psychology of college students participated in the investigation is Aversion learning, Not agree with the teaching contents and Think learning useless, which accounted for 25\%, 20\%, 18\%; because teachers' lack of occupation accomplishment, low level of teaching will lead students to the resistance reversal learning psychology teachers accounted for $12 \%$, and the other rebellious learning psychology also occupies the corresponding proportion.

In the experiment, teachers are required to teach students to use self management assessment methods and the reversal learning psychological counseling. After three months, surveying with reversal learning psychology of higher college students and conducting a questionnaire survey of 45 cases of early participating ones. their own elimination for the psychological inversion is understood, Statistics show that the appearance of 38 cases of reversal learning psychology. Statistics of s student negative mentality was described in table 2 :

Table 2 Statistics of student negative mentality after self management assessment counseling

\begin{tabular}{cccccccccc}
\hline $\begin{array}{c}\text { Negative } \\
\text { mentality } \\
\text { type }\end{array}$ & $\begin{array}{c}\text { Aversion } \\
\text { learning }\end{array}$ & $\begin{array}{c}\text { Contradictin } \\
\text { g teachers }\end{array}$ & $\begin{array}{c}\text { Learning } \\
\text { useless }\end{array}$ & $\begin{array}{c}\text { Not agree } \\
\text { with } \\
\text { teaching } \\
\text { content }\end{array}$ & $\begin{array}{c}\text { Hating } \\
\text { collective } \\
\text { learning } \\
\text { activities }\end{array}$ & $\begin{array}{c}\text { Lack of } \\
\text { ambition }\end{array}$ & $\begin{array}{c}\text { Lack of } \\
\text { clear } \\
\text { goals }\end{array}$ & $\begin{array}{c}\text { Lack of } \\
\text { learnin } \\
\text { g plan } \\
\text { personal } \\
\text { independence } \\
\text { of conduct } \\
\text { personality }\end{array}$ & $\begin{array}{c}\text { Passive } \\
\text { learning }\end{array}$ \\
\hline times & 5 & 6 & 4 & 6 & 4 & 2 & 4 & 2 \\
\hline
\end{tabular}

The analysis of Table 2 show that, several common reversal learning psychological significantly reduced after 3 months of self management assessment. It was proved that self management assessment method proposed in this paper can effectively reduce the students' negative mentality. The comparison of students' negative mentality in tables 1 and table 2 was shown in figure 1.

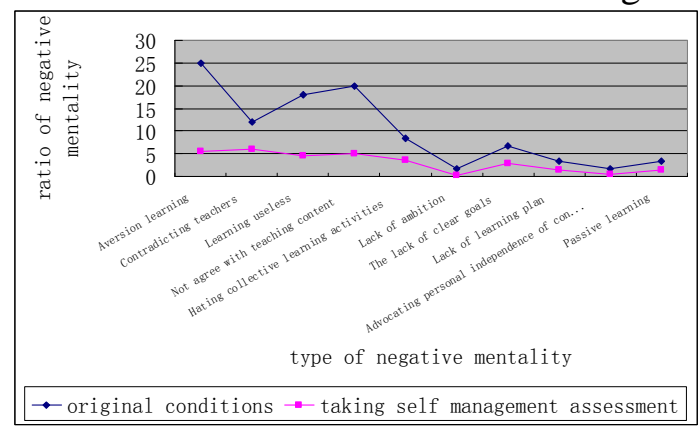

Figure 1 The students' negative mentality comparison chart of self management method and the ori ginal situation

With analysis of Figure 1, it shows that the self management method can dredge the negative mentality of college students effectively. And the ratio of students' negative mentality taking that method was greatly less than before. Therefore, the self management evaluation method proposed in this paper was useful for counseling of negative mentality of college student, which can enhance the enthusiasm of students and improve student achievement. 


\section{Conclusions}

The analysis of this article show that, negative mentality generally exists in higher college students, with the main reasons of the quality of the students themselves, family education and social causes. After the analysis of the manifestations and reasons of higher vocational negative mentality of college students, the self management assessment was proved to realize counseling reverse learning psychology of students, mobilize the enthusiasm of students, and improve the learning achievement.

\section{Reference}

[1] LIU Xu-dong. On Educational Practice Ability of Normal Students and the Reform of Education a nd Internship Program[J]. Contemporary Education and Culture, 2011, 3(2): 74-79.

[2] Collins, Michael. D. The effect of psychological contract fulfillment o manager turnover intentions and its role as a mediator in a casual limited-service restaurant environment[J]. International Journ al of Hospitality Management, 2010, 29(4): 736-742

[3] Chen Chaowen. Discussions on the Reform of Tanching Practice for Computer Science Majors[J]. Journal of Nanning Teachers College, 2005, 22(3):75-77.

[4] DENG Jing-sheng. The new view about reform of the method of pre-service teacher education pra ctice under the background of new curriculum[J]. CAREER HORIZON, 2012, 8(9): 81-83.

[5] Wang Ning, Li Gang. The Research on Online Exhibits Digitizing of Digital Museum[J]. Bulletin of Science and Technology, 2013, 29(2): 178-180.

[6] SHAN Dong-hong, ZHAO Wei-ting. Research on Intrusion Detection System Neural Networks an d Principal Component Analysis[J]. Computer Simulation. 2011; 28(6): 153-156. 